\title{
Optimization the Work of Soil for the Cultivation of Afila Peas in Turda Area
}

\author{
Alina ŞIMON ${ }^{1,2^{*}}$, Teodor RUSU ${ }^{2}$, Felicia CHEȚAN ${ }^{1,2}$, Cornel CHEȚAN ${ }^{1,2}$ \\ ${ }^{1}$ Agricultural Research-Development Station Turda, 27 Agriculturii Street, Turda, 401100, România, \\ ${ }^{2}$ University of Agricultural Sciences and Veterinary Medicine Cluj-Napoca, 3-5 Mănăștur Street, \\ 400372, Cluj-Napoca, România. \\ *Corresponding author: maralys84@yahoo.com
}

Bulletin USAMV series Agriculture 72(2)/2015

Print ISSN 1843-5246; Electronic ISSN 1843-5386

DOI 10.15835/buasvmcn-agr: 11535

\begin{abstract}
By applying minimum tillage system are reduced degradation by erosion, increase organic matter, it restores the soil structure and through the introduction of legumes in rotation ensure a higher nitrogen quantity to crops which are in rotation. Research conducted at SCDA Turda in 2014 following the behavior of four varieties of afila peas in two soil tillage system (classical-with mould plow and with minimum tillage-the chisel variant) and the effect of tillage on the momentary and accessible water reserve from the soil. In the minimum tillage system with chisel obtained a very significant difference of production compared to the classic system $\left(88 \mathrm{~g} / \mathrm{m}^{2}\right)$ at green peas, and if mature pea beans the difference of $-27 \mathrm{~kg} / \mathrm{ha}$ obtained in variant with chisel being insignificant. Through the application of the minimum tillage system at pea get an important economy of $28.4 \%$ in terms of fuel costs ( 337.2 ron/ha) compared to the classic tillage system application (471 ron/ha). For producing a 1 ton peas in classical system is necessary to $21.9 \mathrm{l} / \mathrm{t}$ fuel consumption and fuel costs of $131.6 \mathrm{ron} / \mathrm{t}$, higher than minimum tillage system were fuel consumption are $15.8 \mathrm{l} / \mathrm{t}$ with fuel costs of $94.9 \mathrm{ron} / \mathrm{t}$.
\end{abstract}

Keywords: economic efficiency, peas, soil tillage systems, soil water, yield.

\section{INTRODUCTION}

Climate change is one of the biggest economic threats social and environmental. In the context of climate change there a need to reduce consumption of energy resources, being necessary to adapt the technologies applied as to lead an effective use of available water but increasing soil water reserve (Richter et al, 2007).

By applying minimum tillage system aims to reduce soil erosion (Oliver and Pharr, 2004), improved soil water reserve, qualitative and quantitative production increase, economic efficiency and soil conservation (Ulrich et al, 2006). Cover the soil with a layer of mulch made from vegetable scraps reduce the amount of water evaporated from the soil and surface runoff
(Griffith et al, 1986), restores soil fertility and structure (Guş et al, 2004).

The tillage significantly affects the growth of crops by changing the soil structure and moisture during the period of vegetation. In generally, the changes of soil moisture due to soil tillage are related to some things: soil type, soil tillage equipment, tillage depth and climatic conditions.

Adapting to climate change requires selecting zonate varieties, the optimal time works (Rusu et $a l, 2009)$, plant cultivation in favorable areas and the introduction of legumes into crop. Legumes provide quality protein for humans and animals and enrich the soil with nitrogen by symbiotic fixation with genus Rhizobium bacteria (Singh et $a l, 2007$; Şimon et al, 2014). Peas, one of the most 
suitable legumes cultivated in regions with colder climates, to use both green and mature grains (human and animal nutrition) and secondary production as feed for animals or green fertilizer (Mihailović and Mikic, 2010; Şimon, 2015).

\section{MATERIALS AND METHODS}

The experience, a bi-factorial experience in four repetitions, was studied at ARDS Turda, in 2014, sol type vertic faeozem, pH neutral, with loam-clay texture, medium humus content, good supply in mobile phosphorus and potassium. Pea was sown in the third decade of the March in the quantity of 100 seeds per $1 \mathrm{~m}^{2}$, with the distance between rows $18 \mathrm{~cm}$, with Gaspardo Directa 400 drill. The experiment served to evaluate the yielding of pea cultivated on seeds under conditions of conventional tillage and reduced tillage.

The experimental factors: factor A: soil tillage, with 2 graduation: A1: the classical tillage system included ploughing after harvest of the previous crop in the autumn and disking in spring, A2: the minimum tillage system involved the use of a chisel after harvest of the previous crop and disking in spring; factor B: peas variety, with 4 graduation: B1: Tudor, B2: Dora, B3: Bellmondo, B4: Camilla.

Momentary reserve of soil moisture and plant accesible water reserve was determined through sampling of soil depth at $0-100 \mathrm{~cm}$, using probetype drill and drying of the samples to the steamer for a period of 8 hours at $105^{\circ} \mathrm{C}$.

Climatic conditions during the growing season of the crop of peas are presented in Fig.1 and Fig. 2. From the data presented in Fig. 1 it can be seen that the temperatures recorded in the five

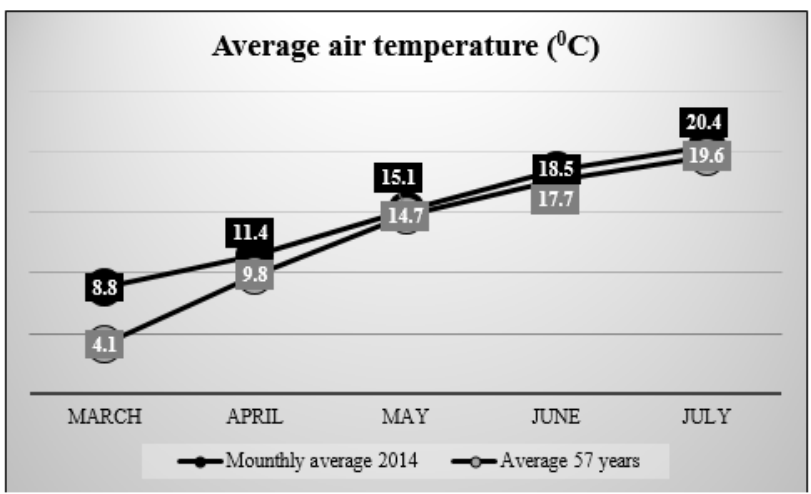

Fig. 1. Thermal regime during the growing season of the pea crop, Turda 2014 months are higher than the average 57 years, the warmest month compared to the average being the month of March when temperatures have been recorded with $4,7^{\circ} \mathrm{C}$ higher than average monthly temperatures on the 57 years.

Values of precipitations in June are lower than the monthly average of 57 years, being considered a very dry month, and the amount of precipitations in the months of April and July is much higher than the monthly average of 57 years, being characterized as excessively rainy months. The amount of precipitations in March and May was normal compared with the average of 57 years.

\section{RESULTS AND DISCUSSIONS}

Precipitations in the winter months but those in vegetative period contributed to increasing soil moisture led to the creation of favorable conditions for emergence and development the culture of pea. The amount of precipitation in March-July period was $354.1 \mathrm{~mm}$, with $57.4 \mathrm{~mm}$ higher than multiannual average.

Momentary reserve of soil moisture is higher in the system with minimum tillage, on all three levels of sampling depth, the root system of the plant may benefit from a larger quantity of water compared to the classical system it can be seen in Fig. 3.

Determinations concerning momentary soil moisture, effectuated at the pea culture, on depth 0-100 cm, highlights a momentary reserve higher than the coefficient of withering, on depth 0-20 $\mathrm{cm}$ with $195.3 \mathrm{~m}^{3} /$ ha at classical system and with $229 \mathrm{~m}^{3} /$ ha at minimum tillage system, on depth $20-50 \mathrm{~cm}$ higher with $190.6 \mathrm{~m}^{3} /$ ha at classical system and with $682.4 \mathrm{~m}^{3} /$ ha at minimum tillage

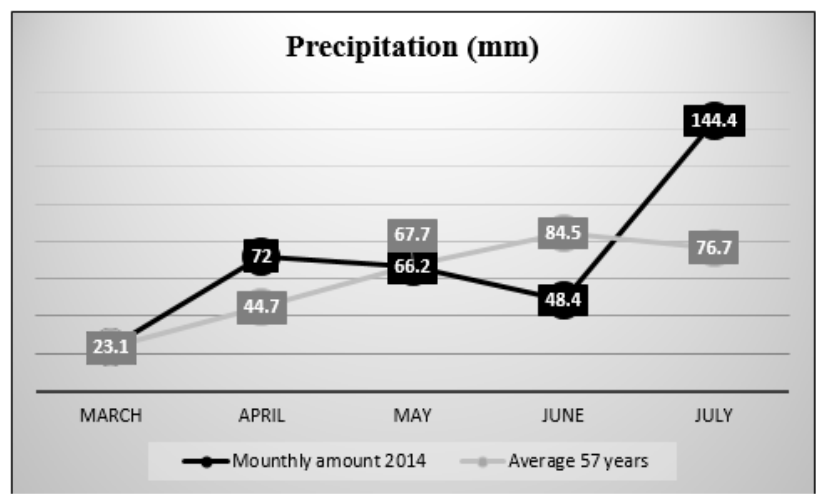

Fig. 2. Pluviometric regime during the growing season of the pea crop, Turda 2014 
system, on depth 50-100 cm higher with 570.6 $\mathrm{m}^{3} /$ ha at classical system and with $957.2 \mathrm{~m}^{3} /$ ha at minimum tillage system throughout the growing season of the crop, the plants water needs being provided from precipitation.

The field capacity was not reached in the months in which determinations were made, the values recorded in the minimum tillage system being close to field capacity than the values recorded in the classic system, the deficit compared with the field capacity being smaller.

Lowering humidity below the minimum limit (503.1 $\mathrm{m}^{3} / \mathrm{ha}$ ), which inherently leads to lower production even though soil moisture reserve are greater than the coefficient of withering, was recorded only in the case of the classic system, in June and July with $10.7 \mathrm{~m}^{3} /$ ha, respectively 34.4 $\mathrm{m}^{3} / \mathrm{ha}$, on $0-20 \mathrm{~cm}$ depth. At the minimum tillage system not recorded humidity momentary values lower than the minimum limit (Fig. 4).

Completion of plant accessible water reserve associated with favorable temperatures have caused a normal development of pea plants in the months of spring, proven fact of pea production obtained in two soil tillage systems.

Crop yielding is a resultant of co-effects of pedo-climatic conditions and agro-technical factors the greatest importance is ascribed to tillage, plant protection and crop rotation.

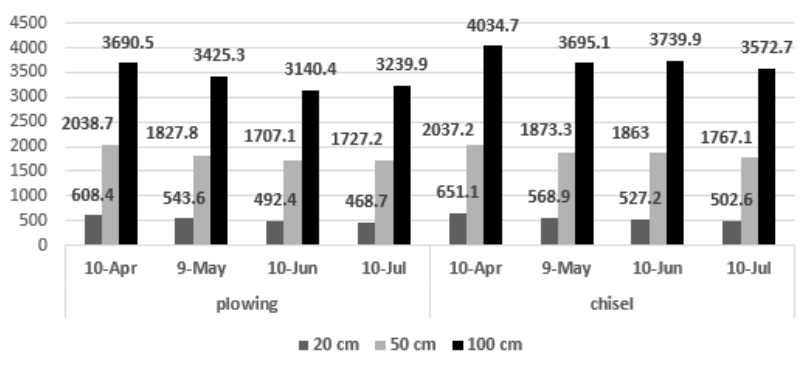

Fig. 3. Momentary reserve of soil moisture $\left(\mathrm{m}^{3} / \mathrm{ha}\right)$
Increase water reserve accessible to plants as a result of the minimum tillage system application (chisel variant) resulted an increase in the production of green peas with $88 \mathrm{~g} / \mathrm{m}^{2}$, the difference compared to the control (classical variant) are very significant (Tab. 1).

The climatic conditions in 2014, favourable year for the pea yield, made as in both system (classic and minimum tillage) the yield obtained exceed $3500 \mathrm{~kg} / \mathrm{ha}$.

The production of mature peas was lower by $27 \mathrm{~kg} / \mathrm{ha}$ in case of the minimum tillage system application compared with classical system, the difference being insignificant (Tab. 2).

The productions varied depending on the variety of the crop, the Bellmondo and Camilla varieties values obtained $3844 \mathrm{~kg} /$ ha respectively $3788 \mathrm{~kg} / \mathrm{ha}$ are higher compared with the control (Tudor variety) in the case of mature pea beans and a little lower at green pea beans production, thus indicating their suitability cultivation in two systems. To green pea beans harvest, the Dora variety had a larger production than the control but insecure statistically (Tab. 3), at mature pea beans harvest the semi-erect stem resulted in very significant production losses (Tab. 4).

For determining the economic efficiency as a result of those two soil tillage systems was made

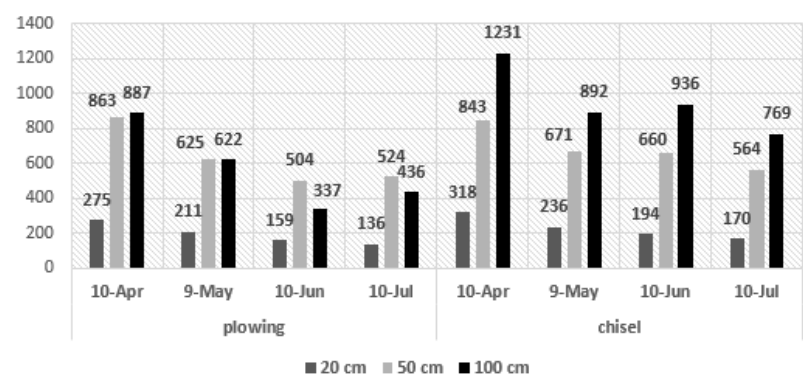

Fig. 4. Plant accessible water reserve $\left(\mathrm{m}^{3} / \mathrm{ha}\right)$

Tab.1. Influence of soil tillage system on the green peas $/ \mathrm{m}^{2}$ production

\begin{tabular}{cccc}
\hline Variant & Yield $\left(\mathrm{g} / \mathrm{m}^{2}\right)$ & Difference & Significance \\
\hline Classic system & 626 & 0 & Mt. \\
\hline Minimum tillage system & 714 & 88 & ${ }^{* * *}$ \\
\hline LSD (p 5\%) & & & 17 \\
\hline LSD (p 1\%) & & 32 \\
\hline LSD (p 0.1\%) & & 71 \\
\hline
\end{tabular}


the reporting of all expenditure per hectare who involved these technologies.

Economic efficiency was calculated only in term of expenditure on materials and fuel, without involving other production expenses. In terms of materials cost, these were equal in the two tillage systems, realizing the economy only fuels needed for achieving culture.

The biggest expenditure made when applying the classical system are those which relate to the soil basic tillage (plowing) and representing $35.7 \%$ of the total fuel expenditure compared with the minimum tillage system were the basic tillage was done with the chisel, cost for the basic tillage being $10.1 \%$ of all expenditure with fuel.
Through the application of the minimum tillage system obtained at pea culture a significant economy of $28.4 \%$ in terms of fuel costs (337.2 lei/ha) compared to the classic system application (471 lei/ha) (Tab. 5). Taking into account the costs of materials the economy of the minimum systems application is $10.64 \%$, that is 133.8 lei/ha (Tab. 6).

To produce 1t of peas (main production) the classical system requires a fuel consumption of $21.9 \mathrm{l} / \mathrm{t}$ and the cost of fuel at $131.6 \mathrm{lei} / \mathrm{t}$ higher than minimum tillage system where the fuel consumption is $15.8 \mathrm{l} / \mathrm{t}$ with a cost of fuel at 94.9 lei/t, reducing the fuel consumption with $28 \%$ as a result of the minimum tillage system application.

Tab. 2. Influence of soil tillage system on the pea production

\begin{tabular}{cccc}
\hline Variant & Yield (kg/ha) & Difference & Significance \\
\hline Classic system & 3580 & 0 & Mt. \\
\hline Minimum tillage system & 3552 & -27 & - \\
\hline LSD (p 5\%) & & 121 \\
\hline LSD (p 1\%) & & 221 \\
\hline LSD (p 0.1\%) & & 490 \\
\hline
\end{tabular}

Tab. 3. Influence of the variety on green pea $/ \mathrm{m}^{2}$ production

\begin{tabular}{ccc}
\hline Variety & Yield $\left(\mathrm{g} / \mathrm{m}^{2}\right)$ & Difference \\
\hline Tudor & 694 & Mt. \\
\hline Dora & 699 & 5 \\
\hline Bellmondo & 618 & $-76^{000}$ \\
\hline Camilla & 669 & $-25^{0}$ \\
\hline LSD (p \%) & & 21 \\
\hline LSD (p 1\%) & 29 \\
\hline LSD (p 0.1\%) & 39 \\
\hline
\end{tabular}

Tab. 4. Influence of the variety on pea production

\begin{tabular}{ccc}
\hline Variety & Yield (kg/ha) & Difference \\
\hline Tudor & 3613 & Mt. \\
\hline Dora & 3020 & $-593^{000}$ \\
\hline Bellmondo & 3844 & $231^{* *}$ \\
\hline Camilla & 3788 & $175^{*}$ \\
\hline LSD (p \%) & \multicolumn{2}{c}{147} \\
\hline LSD (p 1\%) & 202 \\
\hline LSD (p 0.1\%) & 275 \\
\hline
\end{tabular}


Tab. 5. Costs made to the application of the soil tillage system

\begin{tabular}{cccc}
\hline \multicolumn{2}{c}{ Classic system } & \multicolumn{2}{c}{ Minimum system } \\
\hline Tillage performed & Cost/ha (lei) & Tillage performed & Cost/ha (lei) \\
\hline Plowing & 168 & Processing with chisel & 34.2 \\
\hline Disking & 34.2 & Disking & 34.2 \\
\hline Sowing & 30 & Sowing & 30 \\
\hline Sprayer & 9.6 & Sprayer & 9.6 \\
\hline Treatments application & 19.2 & Treatments application & 19.2 \\
\hline Harvested & 210 & Harvested & 210 \\
\hline Total & 471 & Total & 337.2 \\
\hline
\end{tabular}

Tab. 6. Costs made with materials

\begin{tabular}{ccc}
\hline Material & Product & Cost/ha (lei) \\
\hline Seed & Tudor, Dora, Bellmondo, Camilla $(220 \mathrm{~kg} / \mathrm{ha})$ & 308 \\
\cline { 2 - 3 } Herbicides & Tender (1.5 l/ha) & 120 \\
\cline { 2 - 3 } & Pulsar (1.0 l/ha) & 135 \\
\cline { 2 - 3 } Insecticides & Agil (1.0 l/ha) & 85 \\
\hline Foliar fertilizer & Calypso (0.1 l/ha) & 98 \\
\hline & Agrofeed (4 l/ha) & 70 \\
\hline
\end{tabular}

\section{CONCLUSIONS}

Momentary moisture reserve of soil and plant accessible water are greater than the minimum tillage system application plants can use the available water more efficiently.

At the minimum tillage system application haven't recorded momentary moisture values lower than the minimum limit, lowering moisture below the minimum limit was recorded only in the case of the classic system, in June and July on all 3 levels deep.

Peas cultivated in the minimum tillage system received a larger amount of water available to plants, the yield obtained as a result of harvesting green beans being higher compared with the classical tillage system.

By applying minimum tillage system era realizing an economy of $28.4 \%$ to fuel consumption, total economy obtained in the minimum tillage system with chisel application are $10.64 \%$.

To produce $1 \mathrm{t}$ of peas the classical system requires a fuel consumption of $21.9 \mathrm{l} / \mathrm{t}$ higher than minimum tillage system where the fuel consumption is $15.8 \mathrm{l} / \mathrm{t}$, reducing the fuel consumption with $28 \%$ as a result of the minimum tillage system application.

The efficiency of the minimum tillage systems application are confirmed only when the yield achieved made relate to all of the factors involved in getting it, in particular, the total expenditure required to implement the technology.

\section{REFERENCES}

1. Griffith DR, Mannering JV and Box JE (1986). Soil and moisture management with reduced tillage, No-tillage and surface-tillage agriculture, Wiley, New York: 19-55.

2. Guș P, Rusu T, Cernea S and Bogdan Ileana (2004). Sisteme de semănat, fertilizat şi întreținere a culturilor, Editura Risoprint, Cluj Napoca.

3. Mihailović V and Mikić A (2010). Novel directions of breeding annual feed legumes in Serbia. Proceedings, XII International Symposium on Forage Crops of Republic of Serbia, Kruševac, Serbia: 81-90.

4. Oliver WC and Pharr GM (2004). Measurement of hardness and elastic modulus by instrumented indentation: Advances in understanding and refinements to methodology, J. Mater. Res., Vol. 19, No. 1: 3-20.

5. Richter GM, Lawlor DW, Latiri K, Acutis M and Qureshi $K$ (2007). Field scale water-use efficiency inherent variability and options for crop selection and management, Workshop: how to advance the knowledge on water use 
efficiency in the Mediterranean region?, Bari, Italy: 93100.

6. Rusu T, Guş P, Bogdan I, Moraru PI, Pop A, Clapa D, Doru IM, Oroian I, and Pop LI (2009). Implications of Minimum Tillage Systems on Sustainability of Agricultural Protection and Soil Conservation, Journal of Food, Agriculture \& Environment, vol. 7 (2/2009): 335-338.

7. Singh RJ, Chung GH and Nelson RL (2007). Landmark research in legumes, Genome 50: 525-537;
8. Simon A, Chetan F, Chetan C, Ignea M and Deac V (2014). Rezultate privind influența densității şi a fertilizării asupra producției la soiurile de mazăre de tip afila, AN. I.N.C.D.A. Fundulea, LXXXII: 227-232.

9. Şimon Alina (2015). Mazărea-Tehnologia de cultivare în Transilvania, Agricultura Transilvană, Buletin informativ, 22: 55-58.

10. Ulrich S, Hofmann B, Tischer S and Christen O (2006). Influence of Tillage on Soil Quality in a Long Term Trial in Germany, In Soil Management for Sustainability: 110-116. 